\title{
A MULTI CRITERIA DECISION URBAN DEVELOPMENT FRAMEWORK FOR LAND EXPROPRIATION IN SOUTH AFRICA: A STRATEGIC APPROACH
}

\author{
B.T. Mokoena ${ }^{1 *}$ and J.P. Sebola ${ }^{2}$ \\ ${ }^{1}$ City of Ekurhuleni, Human Settlements Department, 29 Lakeview Crescent, Kleinfontein Lake Office Park, Benoni, 1537, South \\ Africa - balesengmokoena211@gmail.com \\ ${ }^{2}$ Dept. of Architecture and Planning, University of Witwatersrand, 1 Jan Smuts Avenue, Braamfontein, 2000, Johannesburg, South \\ Africa - jackoson.sebola@wits.co.za
}

KEY WORDS: Smart Cities, MCDA, AHP, Strategic Planning, Land, Expropriation, Strategic Urban Development, Frameworks, Planning Support Systems

\begin{abstract}
:
The land question in South Africa has been a long-standing issue for more than 360 years. Consequent to unjust legislation such as The Natives Land Act No.27 of 1913 to this day, there is a racial imbalance in the distribution of land ownership in South Africa. Coupled with the socio-economic and spatial segregative mandates of the apartheid-government to enrich the white minority, such unjust legislation fostered mass-land dispossessions and displacements of black people relocating them to peripheral areas known as 'Bantu stands' where they were further ethnically grouped in remote from socio-economic opportunities. The preceding has resulted in the impoverishment of the black people as they no longer had land - their primary source of livelihood. The limited access to land by black people remains true in post-apartheid South Africa.
\end{abstract}

Since the dawn of democracy, limited access to urban land has coursed challenges for housing development. Spatial transformation towards socio-economic integration has also become problematic as large areas of strategically located land remain locked in the hands of the minorities. Thus, to realise the mandates of South Africa's democratic government - equal access to land and opportunities, this land needs to be acquired, particularly for the previously disadvantaged, poor, and landless.

As cities move towards being smart, this research will demonstrate the use of Evidence Based Planning (EBP) in order to assist Local Government to foster scientific decision making methods. The use of the Multi-Criteria Decision Analysis (MCDA), Analytical Hierarchy Process (AHP) and Geographic Information System (GIS) as a method to develop a Strategic Urban Development Decision Framework (SSUDDF) as a Planning Support System (PSS) that will be used to investigate the best suitable land for possible expropriation. Various criteria such as proximity to road connectivity, proximity to current and future economic activity, proximity to public transport routes, dolomitic land, priority areas and proximity to city centres are some of the criteria selected for the research. The Strategic Spatial Urban Development Decision Framework (SSUDDF) enabled us to stream line significant criteria and processes that where specific to strategic urban development in the Benoni town situated in the City of Ekurhuleni using critical spatial policy and strategic objectives of the city.

\section{INTRODUCTION}

\subsection{Background}

South African spatial form is largely shaped by the colonial and apartheid past, whose effects still exist even today (Todes, 2012; Harrison, P. and Todes, 2015). By separating people according to race, black people where mainly placed far from economic opportunities and by that creating an unequal spatial form that placed certain races at a more advantaged place (Mokoena, Musakwa, Moyo, 2017; Turok,, 2013). In locations that created a better living experience for some. Using legislation such as the Group Areas Act of 1950 it enabled this spatial form to become possible by separation (Todes, 2012; Harrison, P. and Todes, 2015). In 1994 when South Africa became a democratic country, the urban planners mandate began to officially change in order to transform the spatial form of the country. In doing this, a number of urban planning legislation and policy where developed to transform this space to become sustainable, compact and inclusive for all. With the recent policies such as the Breaking New Ground 2004 that placed an emphasis on the location of public housing development where an estimated 2 million of housing was development by this time. The National Development Plan, formulated in 2011 , in its $8^{\text {th }}$ chapter again was founded on developing sustainable and smart Human Settlements. The Spatial Planning and Land Use Management Act 16 of 2013 is a recent legislation that advocates for spatial principles that creates inclusive urban and rural spaces, such as spatial justice, spatial sustainability, efficiency, resilience and good administration. However, the availability of land is very often limited in order to enable the state or local government to achieve its transformed, inclusive and sustainable urban development mandate. Through the 1913 Land Act black people where dispossessed of their land and because of this the land ownership is still unequal to this day. Additionally State owned land is not sufficient to fulfil its development mandate by way of service delivery. As cities become smart there is a need to apply more scientific ways through Evidence Based Planning for better decision making. The aim of this paper is then to explore the development of a Spatial Urban Development Decision Framework that makes use of a GISMCDA methodology to find inclusive and strategic land for urban development purposes through constitutional land 
expropriation. The Literature review section explores the land question in South Africa and land expropriation. Additionally smart cities and planning support systems are further discussed. The Strategic Spatial Urban Development Decision Framework (SSUDDF) and its methodological approach is discussed using the City of Ekurhuleni, Benoni as a study area, followed by the conclusion.

\section{LITERTURE REVIEW}

\subsection{The land question in South Africa}

For more than three centuries land has been a pertinent issue in South Africa which has resulted to unjust colonial mass-land dispossession, land expropriations through the Native Land Act No. 27 of 1913, and apartheid land dispossessive and spatialsegregative legislations (Feinstein, 2005). Van Wyk (2013: 91) notes, "this statute [Native Land Act of 1913] signalled the commencement of legalised discriminatory land legislation in the country". As a consequent to the preceding unjust land occurrences, millions of black people were dislocated from their historical lands to areas demarcated solely for black occupation; referred to as Black Spots, Bantustans, Homelands and Native areas (Murray, 2008). In the process, such of massdispossessions, expropriations and dislocations a lot was forfeited beyond people's sacred historical land - people lost their livestock (a source of African wealth); source of livelihood; indigenous agricultural, cultural and traditional practices; and more importantly their sense of pride and identity. This forced black people to peripheral margins of poor land quality simultaneously compelling them to work as fulltime servants, migrant workers, and farmworkers (Murray, 1990).

The said scheduled black land areas amounted to approximately 21 million acres, amounting to a mere $7.3 \%$ to $13 \%$ of South Africa total land area, while on the other hand, the area, set aside for the white minority, was exceedingly larger than that of the black majority at $87 \%$ (Letsoalo, 1987; Feinberg and Horn, 2009). After the promulgation of the 1913 Native Land Act, the outcomes of land ownership spoke volumes. Towards the end of apartheid in 1990, an estimated 82 million hectares of commercial farmland which was about $86 \%$ of total agricultural land, was in the hands of the white minority who constituted about $10.9 \%$ of the country's total population (Davenport, 1990).

In this regard, at the centre of South Africa's land reform programme, is addressing the land question by redressing the past caused socio-economic and spatial injustices - beyond just the mere quantitative measures of achieving targets. In 1994, by implementing three core-approaches, namely land restitution, land redistribution, and security of tenure (see Gibson, 2009) the government set a target for the land reform program to transfer $30 \%$ of white-owned agricultural land within five years. The target was not met, it was extended to twenty years (2014), and again it was not met. Consequently, the government has currently further extended the target to 2030 (NDP, 2030). From its target to transfer $30 \%$ of about 62 million hectares of commercial land held by $10.9 \%$ of the population -25 years later and only 8.4 million hectares has been availed for land (DALRRD, 2019).

This year marks 107 years since the enactment of the Natives Land Act - which is provided by the Constitution of the
Republic of South Africa Act 108 of 1996 to be the earliest date referred to concerning land dispossession in South Africa (See Republic of South Africa, 1996). Regrettably, the Natives Land Act's legacy persists, as its socio-economic and spatial injustice outcomes are very much alive in South Africa's post-apartheid dispensation - witnessed through the current unequal racial ownership of land and wealth. In essence past matters on land are the arch-course of the country's current socio-economic disparity. Land reform in South Africa is no doubt faced with many challenges as listed above, the most significant being' time' - it is indeed way behind schedule. Moreover, one of the core reasons for the slow pace of land reform is the willingbuyer willing-seller model which has ultimately shifted land reform discourses and trajectories towards a more radical approach, one that advocates for land expropriation without compensation.

\subsection{Land Expropriation}

Close to three decades of land reform have yielded unsatisfactory results, generating, in the process, radical debates on the land reform direction in the country towards a land expropriation without compensation trajectory. The Constitutional court of South Africa has defined expropriation as "a process whereby a public authority takes immovable property for a public purpose and usually against payment of compensation".

However, concerning land expropriation in South Africa's legislative framework, it has been argued by far-left proponents that Section 25(2) of the Constitution that provides for land expropriation has two elements that 'constrain' the state's power to expropriate property. The first constraint is that expropriation is permissible only for public purposes or in the public interest. Section 25 (4)(a) provides that the public interest includes the nation's commitment to land reform to bring about equitable access to all South Africa's natural resources. It is the second constraint that is said to hampered on the speedy implementation of land reform. This constraint has been realised by the government as a catalyst to the slow-limitation of the willing-buyer willing-seller concept - stating that; 'an expropriation is subject to payment of compensation for the property that has been taken'; as provided by Expropriation Act of 1975 .

This has led to processes of the amendment of Section 25 of the Constitution to enable the enactment of the 2019 Draft Expropriation Bill ${ }^{1}$; which will establish a legislative provision for the expropriation of land without compensation, and repeal the Expropriation Act of 1975 (RSA, 2019). Such an exercise has been recognised as a critical enabler to fast-tracking the South African land reform process land reprocess. On the other hand, however, there is a school of thought that argues that the Constitution need not be amended, particularly if it is read and interpreted in relation with a redistributive purpose (Jankielsohn and Duvenhage, 2018). These arguments are further echoed by contentions that such an approach may have undesirable consequences if it tempers with agricultural production - given that agricultural production is a primary source of livelihood for more than $80 \%$ of the rural population South Africa (Worth and Abdu-Raheem, 2011; RSA, 2019a ${ }^{2}$ ).

\footnotetext{
The Bill was published on 21 December 2018.

${ }^{2}$ See report by an Expert Advisory Panel on Land Reform and Agriculture, released in July 2019 (RSA, 2019a).
} 
Nonetheless, in as far as land expropriation is concerned, a critical question to ask is; whether the current land reform programme, as well as beneficiaries, have the capacity and resources to transform the influx of appropriated land into a sustainable socio-economic commodity for the urban and rural poor? Fortunately, the state finds itself once again in a proactive land reform position; as the DALRRD had begun to answer this critical question partly - by shifting the focus of land reform beyond just the rural and agricultural but also towards urban human settlement purposes - a core discussion-component of this paper. The (DALRRD, 2019: 2) notes: "Work is also being undertaken to address urban land reform which has not received adequate attention in the past, in order to assist in driving spatial transformation in our cities". This paper argues that the preceding intention to prioritise urban land reform by the DALRRD proactively has come at a precise dovetailing period, as South Africa has begun witnessing a shift towards the establishment of urban mega-human settlements projects.

\subsection{Smart Cities and Planning Support Systems (PSS)}

As cities constantly evolve in the digital world, technology, in recent times, has shaped how cities function and how they are managed from a sustainable perspective. Critical to the land question, transport Systems, by way of example, are the engine of cities, transporting people from one area to another (Caragliu, Del Bo, and Nijkamp, 2011). The complexity of managing these systems can be simplified through technology. With an increase of cycling over the years, smart velomobility, a term explored by Behrendt (2016) to describes the concern of systems and technology as well as networked practices around cycling, has become more prevalent in how cities can be designed to become more bicycle friendly (Behrendt, 2016). Ebikes have thus also emerged as a new mode of smart public transport in cities, stemming from the need to further curb the environmental impacts that other transport systems may pose (Behrendt, 2016). However, in developing countries, such as South Africa, areas such as townships ${ }^{3}$ have not fully utilised this mode of transport, due to either lack of funds as well as political buy in (Makoni, Mokoena \& Moyo, 2019). Furthermore, the sprawled spatial form does not allow modes such as cycling to be fully utilised in South African cities (Makoni, Mokoena \& Moyo, 2019). However this does not take away from the enormous benefits of using smart nonemotorised-transport and how they can contribute towards creating smart cities in conjunction with other modes such as the Bus Rapid Transport (BRT) system.

Using cycling as a point of departure, Behrandt (2016) further argues that because of the way cities are largely designed with a bias towards motorcars, the politics of transport planning automatically excludes and marginalises the use of technology in cycling from the smart city agenda. Therefore it is found that the physical infrastructure of cities is yet to fully incorporate smart none-motorised transport such as cycling or e-bikes into many cities around the world (Behrandt, 2016).

Equally, smart economies, smart people, smart environments, smart living and smart governance are topics that are widely researched and explored, nonetheless within the urban planning environment, Planning Support Systems (PSS) which have been developed as a smart way to finding solutions to multifaceted challenges in cities (Caragliu, Del Bo, and Nijkamp, 2011) by

\footnotetext{
3 In South Africa, township are normally referred to as were black people were
} placed during apartheid in order to segregate urban areas according to race researchers, urban practitioners and policy makers. Smart cities from a technological perspective are often referred to as "Digital Cities" or 'Intelligent Cities'. These terms are synonymous with the ability of ICT to merge with traditional infrastructure in order to be integrated and coordinated using new digital technologies (Exner, 2015). Exner (2015) also demonstrates that smart cities don't only have to be associated with technology but they can also be a place were governance and the economy are driven by entrepreneurship and creativity as well as innovation driven by smart people. Additionally smart cities can be described as an inclusive place that uses innovative and technological solutions to combat poverty and deprivation as well foster social inclusion (Exaner, 2015).

As data is constantly collected and analysed, the development of Planning Support Systems has thus made it easier for urban practitioners to confront decision making tasks with more efficiency and flexibility using smart technology (Geertman, and Stillwell, 2004; Pelzer, 2014). Planning Support Systems can be defined as computer based systems that are able to support activities of urban planning practitioners (Russo and Pettit, 2015). It is therefore evident that urban practitioners frequently engage in decision making on a daily basis with the assistance of technology to enable smart cities to become a reality.

It is then found that, Planning Support Systems can consequently assist urban planners engage in more Evidence Based Decision Making (EBDM) rather than unscientific judgments (Faludi and Waterhout, 2006) in order to come up with ways of finding suitable land for housing purposes. EBDM is consequently crucial if more objective rather than subjective decisions are to be made (Faludi and Waterhout, 2006; Barton \& Harphan, 2010; der Heide, 2006; Krizek, Forysth, and Slotterback, 2009). EBDM is further described as a collection and use of valid and reliable data to allow for more wellinformed findings or decision making (Faludi and Waterhout, 2006; Barton \& Harphan, 2010). The methodology chosen for the paper is centred around literature on methods that will assist cities such as Ekurhuleni make well informed urban development decisions through the Multi Criteria Decision Analysis, for expropriation purposes.

\section{STUDY AREA}

The City of Ekurhuleni is a metropolitan municipality that has a population of 3178470 and has an area of $1975 \mathrm{~km}^{2}$. Contributing nearly a quarter of the Gauteng province's economy and a third of the national Gross Domestic Product, it is well known an industrial and transport hub. The city has recently identified itself as an Aerotropolis because of its international airport and has consequently recognised the economic and social benefits of this could have. The Ekurhuleni Aerotrpolis Land Use Strategy has already identified a number of areas that will bring future economic development across the municipality. These areas are across the municipality in both affluent and previously disadvantaged areas. In this research we focus specifically on the Benoni Area to sample how the model can be developed as framework for the entire metropolitan municipality. Situated at the heart of Ekurhuleni, Benoni, $26^{\circ} 11^{\prime} 18^{\prime \prime} \mathrm{S} 28^{\circ} 19^{\prime} 14^{\prime \prime} \mathrm{E}$, has a population of 158777 with a density of $900 / \mathrm{km}^{2}$. As a dynamic town consisting of a CBD, industrial areas, very good rail and road connectivity, peri urban arewas, its dynamic nature allows us to demonstrate how well 
located urban development areas can be identified using the MCDA-GIS.

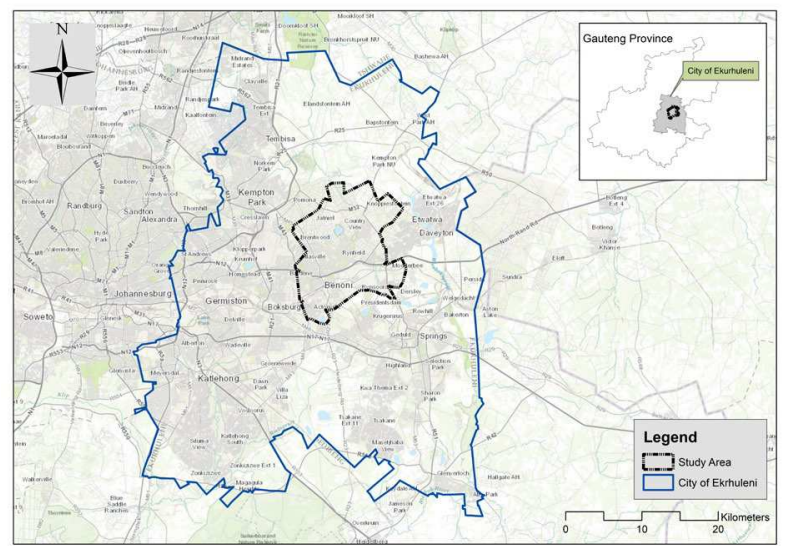

Figure 1: City of Ekurhuleni

\section{A STRATEGIC URBAN DEVELOPMENT DECISION FRAMEWORK (SUDDF)}

Local governments and the state are constantly mandated to develop social amenities such as clinics, hospitals, libraries, Schools, housing and public transport infrastructure etc, but the availability of land to develop these is often a problem due an insufficient amount of state owned land located in strategic areas. The inequalities of the land ownership between black and white has also become an increasing concern over the years as the inequality remains significantly large (Ntsebeza, and Hall, 2007; May, J. and Govender, J., 1998; Parnell and Pieterse, 2010). The expropriation of land has therefore become a burning topic and increasingly become more and more urgent (Ntsebeza and Hall, 2007) and necessary if urban development is to take place in strategic locations. According to various scholars state owned land is often not well located and is used by municipalities to further develop on the outskirts next to previously disadvantaged areas (Harrison, and Huchzermeyer, 2003; Moyo, 2005; Moyo, S., 2007). By doing this, it further perpetuates apartheid planning which was designed to segregate people according race (Harrison, and Huchzermeyer, 2003).

\subsection{GIS-Multi-Criteria Decision Analysis (MCDA) and Analytical Hierarchy Process (AHP)}

One of the new decision-making tools in urban Planning is the relationship created between two different disciplines, namely Geographic Information Science and Multi-Criteria Decision Analysis (GIS-MCDA) (Malczewski and Rinner, 2015). MultiCriteria evaluation is described by Santé-Riveira, CrecenteMaseda and Miranda-Barrós (2008) as a weighted linear procedure that is frequently used to derive suitability maps. Geographic Information Systems has also been in the lead in quantifying multiple factors to meet various spatial goals in urban planning (Rybarczyk and $\mathrm{Wu}, 2010$ ) and according to Rybarczyk and Wu (2010) transport planning.

One of the widely used techniques for decision making is the Weighted Sum Model (WSM) (Velasquez and Hester, 2013). The Weighted Linear Combination (WLC) can also be used in the ArcGIS software, where $S_{\prod}$ the total-score of the welllocatedness for a land unit is calculated using this equation:

$$
s_{i}=\sum_{i=1}^{n} w_{i} P_{i}
$$

Where $W_{\mathbb{1}}$ of each is calculated using the AHP, $P_{\mathbb{1}}$ represents the value of each criteria based on corresponding standards and $n$ is the number of criteria.

The Mutli-Criteria Decision Method (MCDM) makes use of numerical techniques to assist in choosing between a discrete set of alternative choices (Triantaphyllou, 2000; Velasquez and Hester, 2013). The Analytical Hierarchy Process (AHP) is also one of the widely used methods used in Multi Criteria Decision Analysis (MCDA) (Fong and Choi, 2000; Velasquez and Hester, 2013; Saaty, 2008). It was developed by Thomas L. Saaty (1980) (Fong and Choi, 2000; Velasquez and Hester, 2013 ) to quantify relative weights on a ratio scale of a given set of criteria (Akarte et al, 2001). The difference between the AHP and other decision making methods is that during the decision making process it provides a comprehensive structure for combining the instinctive irrational and rational value; it also checks consistency in the decision making process (Akarte et al, 2001).

\subsection{The criteria selection process for the Strategic Spatial Urban Development Decision Framework (SSUDDF)}

In the decision making process, the outcome of the planning decisions may differ based on the kind of stakeholders involved as well as analysts depending on what kind of techniques they use to make these decisions (Myagmartseren, Buyandelger, and Brandt, 2017). Traditionally, there are four steps to the urban planning process and the first one being, to analyse the situation, 2 to establish your goals, 3 framing possible courses of action and 4 comparing and evaluating the consequences of action (Yigitcanlar, and Teriman, 2015). Urban planners deem this as rational thinking (Yigitcanlar and Teriman., 2015). Having said that, the selection process for strategic urban development is made easier using a combination of GIS and MCDA as a spatial analysis tool to find new strategic areas for sustainable urban development, for example.

Rather than looking at each criteria individually the GIS based MCDA takes data (inputs) and combines them into a weighted map which then becomes the output. With this type of technology advances, more and more local governments and community groups are utilising this technique in order to make better decisions for the cities and communities. 


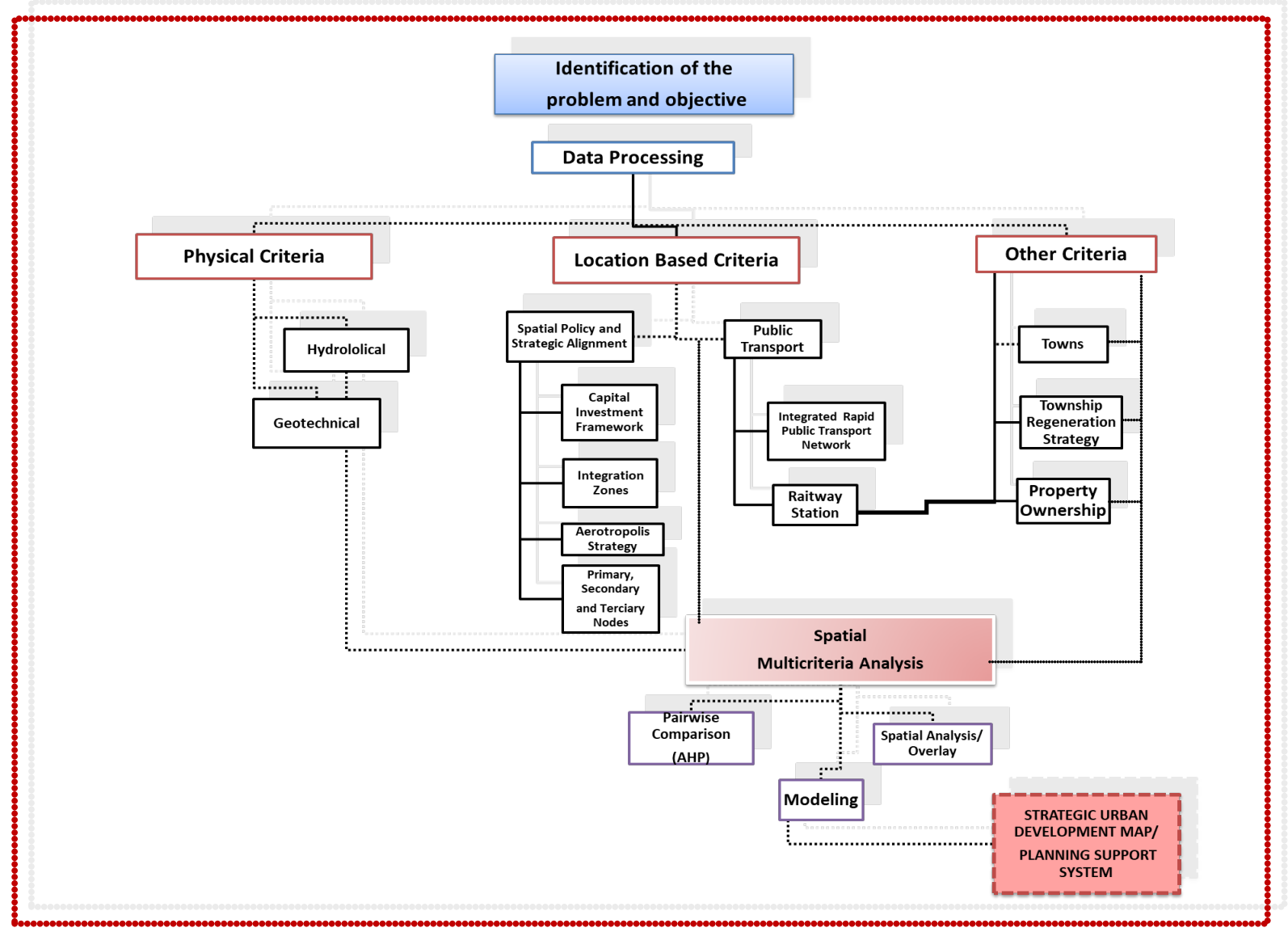

Figure 2: Strategic Spatial Urban Development Decision Framework (SSUDDF)

There are two fundamentals that make up the successful implementation of Spatial MCDA:

1. The user needs to demonstrate GIS capabilities of data analysis, manipulation, retrieval, storage and acquisition.

2. The ability of combining decision making preferences and geographical data into unidimensional values of alternative decisions.

Furthermore, in any decision making technique that requires numerical analysis of alternatives, there are three steps that are taken (Velasquez and Hester, 2013). The first is to determine the relevant alternatives and criteria; the second is to place a numerical measure to the relative impact of the alternative on these criteria as well as the importance of the criteria (Velasquez and Hester, 2013). The third step is to determine a ranking of each alternative by processing the numerical value (Velasquez and Hester, 2013).

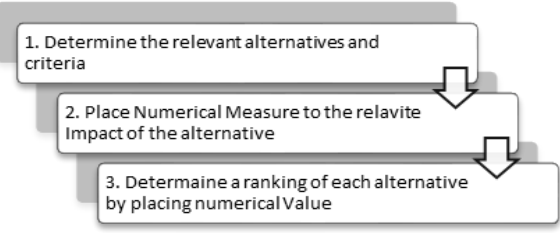

Figure 3: Decision Making Process
The criteria selected has therefore been divided into three, based on physical requirements for development to take place, the locational requirements as well as other criteria that may add value to the process. The framework largely makes use of urban planning instruments set in place for urban development to take place in strategic areas. The City of Ekurhuleni has development various Spatial Development tools such as the Capital Investment Framework, the Integration Zones as well as the IRPTN to channel development. The criteria included in the Strategic Urban Development Location Framework is further described and in the below table.

Table 1: Criteria to Identify Strategic location for urban development

\begin{tabular}{|l|l|l|}
\hline Category & Criteria & Description and Rational \\
\hline $\begin{array}{l}\text { Physical } \\
\text { Criteria }\end{array}$ & Hydrology & $\begin{array}{l}\text { Wetland Data: The Ekurhuleni } \\
\text { Municipality is largely affected by } \\
\text { Wetland constraints which may pose as } \\
\text { a challenge for development. Additional } \\
\text { it has a number of lakes dams and pans. }\end{array}$ \\
\hline Geotechnical & $\begin{array}{l}\text { Dolomite and Undermining Data: It is } \\
\text { critical to incorporate this dolomite data } \\
\text { as a little more the } 50 \% \text { of the City is } \\
\text { affected by dolomite and depending on } \\
\text { the risk levels a more detailed study } \\
\text { would have to be done to determine } \\
\text { further developability. The mining belt } \\
\text { in Ekurhuleni runs across Germiston, } \\
\text { Boksburg as well as the Benoni town. } \\
\text { Shallow undermining is a development }\end{array}$ \\
\hline
\end{tabular}




\begin{tabular}{|c|c|c|c|}
\hline & & \multicolumn{2}{|c|}{$\begin{array}{l}\text { constraint that must be taken into } \\
\text { consideration before any development } \\
\text { could take place }\end{array}$} \\
\hline \multirow[t]{6}{*}{$\begin{array}{l}\text { Location } \\
\text { Based } \\
\text { Criteria }\end{array}$} & \multirow[t]{3}{*}{$\begin{array}{l}\text { Spatial } \\
\text { Policy and } \\
\text { Strategic } \\
\text { Alignment }\end{array}$} & $\begin{array}{l}\text { Capital } \\
\text { Investment } \\
\text { Framework }\end{array}$ & $\begin{array}{l}\text { The capital } \\
\text { Investment } \\
\text { Framework is a } \\
\text { Spatial targeting } \\
\text { tool that aims at } \\
\text { channelling } \\
\text { development along } \\
\text { strategic routes in } \\
\text { the city. }\end{array}$ \\
\hline & & Integration Zones & $\begin{array}{l}\text { The Integration } \\
\text { Zones are another } \\
\text { Spatial targeting } \\
\text { tool aimed at } \\
\text { creating an } \\
\text { integrated and } \\
\text { inclusive City }\end{array}$ \\
\hline & & $\begin{array}{l}\text { Aerotropolis } \\
\text { Project location }\end{array}$ & $\begin{array}{lr}\text { The City of } \\
\text { Ekurhuleni has } \\
\text { recently identified } \\
\text { itself as an } \\
\text { Aerotropolis rity } \\
\text { and } \\
\text { subsequently has } \\
\text { identified sites } \\
\text { across the metro } \\
\text { that would create } \\
\text { future economic } \\
\text { opportunities linked } \\
\text { to the airport land } \\
\text { uses. }\end{array}$ \\
\hline & & $\begin{array}{l}\text { Primary and } \\
\text { secondary Nodes }\end{array}$ & $\begin{array}{l}\text { The Primary and } \\
\text { Secondary Nodes } \\
\text { are selected in the } \\
\text { framework as they } \\
\text { are dubbed as areas } \\
\text { of growth, } \\
\text { diversity, vibrancy } \\
\text { that are } \\
\text { characterised by } \\
\text { mixed development }\end{array}$ \\
\hline & $\begin{array}{l}\text { Public } \\
\text { Transport }\end{array}$ & $\begin{array}{lr}\text { Integrated } & \text { Rapid } \\
\text { Transport } & \text { Bus } \\
\text { Network } & \\
\text { (IRPTN) } & \end{array}$ & $\begin{array}{l}\text { The IRPTN is a } \\
\text { Public transport } \\
\text { network strategy } \\
\text { that not only } \\
\text { integrates the city } \\
\text { but also links the } \\
\text { city to various } \\
\text { destinations } \\
\text { through smart rapid } \\
\text { public bus } \\
\text { transport. }\end{array}$ \\
\hline & & Railway Stations & $\begin{array}{l}\text { A large number of } \\
\text { people use the train } \\
\text { to commute to and } \\
\text { from work. The city } \\
\text { has a very strong } \\
\text { rail network }\end{array}$ \\
\hline $\begin{array}{l}\text { Other } \\
\text { Criteria }\end{array}$ & Towns & $\begin{array}{l}\text { There are nine } \\
\text { Ekurhuleni that a } \\
\text { and residential opr }\end{array}$ & $\begin{array}{l}\text { BD's in the City of } \\
\text { linked to economic } \\
\text { ortunities. }\end{array}$ \\
\hline & $\begin{array}{l}\text { Township } \\
\text { Regeneration } \\
\text { Strategy }\end{array}$ & $\begin{array}{l}\text { There are four } \\
\text { selected by the Na } \\
\text { aim at revi } \\
\text { disadvantaged ar } \\
\text { located on the p } \\
\text { activity and shou } \\
\text { future urban de } \\
\text { township comp } \\
\text { situated in the Sor } \\
\text { East, Daveton in } \mathrm{t}\end{array}$ & $\begin{array}{l}\text { ownship Complexes } \\
\text { ional Treasury which } \\
\text { alising previously } \\
\text { as. These are all } \\
\text { riphery of economic } \\
\text { d be incorporated in } \\
\text { elopment. The four } \\
\text { exes are, Katorus } \\
\text { h, Kwatsaduza in the } \\
\text { e east and Tembisa in }\end{array}$ \\
\hline
\end{tabular}

\begin{tabular}{|c|c|c|}
\hline & & the north of the city. \\
\hline & $\begin{array}{l}\text { Property } \\
\text { Ownership }\end{array}$ & $\begin{array}{l}\text { The city of Ekurhuleni has a land } \\
\text { ownerhship database linked to the } \\
\text { billing systems. This data can be useful } \\
\text { to identify were the state and local } \\
\text { government owned land is located. It } \\
\text { would also be useful if the city had an } \\
\text { updated Vacant Land Audit done in } \\
\text { order to get accurate and recent data to } \\
\text { overlay in an analysis. }\end{array}$ \\
\hline
\end{tabular}

\subsection{Spatial Multi Criteria Analysis}

When using a GIS based MCDA it is vital to develop rule sets that will enable you to set the parameters that will determine, when developing the model, the well locatedness ${ }^{4}$ of an area. This is largely based on the problem you would like to solve. According to the criteria selected and the study area chosen, used as suitability scales of $1-3$, where 1 is very well located or highly suitable, 2 is moderately suitable and 3 as not well located as can be seen from table three.

Table 2: Criteria and rule sets

\begin{tabular}{|l|l|l|l|}
\hline \multicolumn{1}{|c|}{ Criteria } & $\begin{array}{l}\text { Very Well } \\
\text { Located }\end{array}$ & $\begin{array}{l}\text { Moderately } \\
\text { well located }\end{array}$ & $\begin{array}{l}\text { Not Well } \\
\text { Located }\end{array}$ \\
\hline Dolomite & $\begin{array}{l}\text { Areas } \\
\text { without } \\
\text { dolomite }\end{array}$ & $\begin{array}{l}\text { Areas } \\
\text { without } \\
\text { dolomite }\end{array}$ & $\begin{array}{l}\text { Areas with } \\
\text { dolomite }\end{array}$ \\
\hline $\begin{array}{l}\text { Proximity to } \\
\text { Integration } \\
\text { Zones }\end{array}$ & $<1 \mathrm{~km}$ & $1-2 \mathrm{~km}$ & $>3 \mathrm{~km}$ \\
\hline $\begin{array}{l}\text { Proximity to } \\
\text { CIF }\end{array}$ & $<1 \mathrm{~km}$ & $1-2 \mathrm{~km}$ & $>3 \mathrm{~km}$ \\
\hline $\begin{array}{l}\text { Proximity to } \\
\text { IRPTN }\end{array}$ & $<1 \mathrm{~m}$ & $1 \mathrm{~km}-3 \mathrm{~km}$ & $>3 \mathrm{~km}$ \\
\hline $\begin{array}{l}\text { Proximity to } \\
\text { Railway } \\
\text { Stations }\end{array}$ & $<500 \mathrm{~m}$ & $500 \mathrm{~m}-1 \mathrm{~km}$ & $>1 \mathrm{~km}$ \\
\hline $\begin{array}{l}\text { Proximity to } \\
\text { Aerotropolis }\end{array}$ & $>1 \mathrm{~km}$ & $1-2 \mathrm{~km}$ & $>2 \mathrm{~km}$ \\
\hline $\begin{array}{l}\text { Proximity } \\
\text { Primary } \\
\text { Nodes }\end{array}$ & $<2 \mathrm{~km}$ & $2-4$ & $>4$ \\
\hline $\begin{array}{l}\text { Proximity to } \\
\text { Towns }\end{array}$ & $>1-3 \mathrm{~km}$ & $3-4 \mathrm{~km}$ & $>4 \mathrm{Km}$ \\
\hline
\end{tabular}

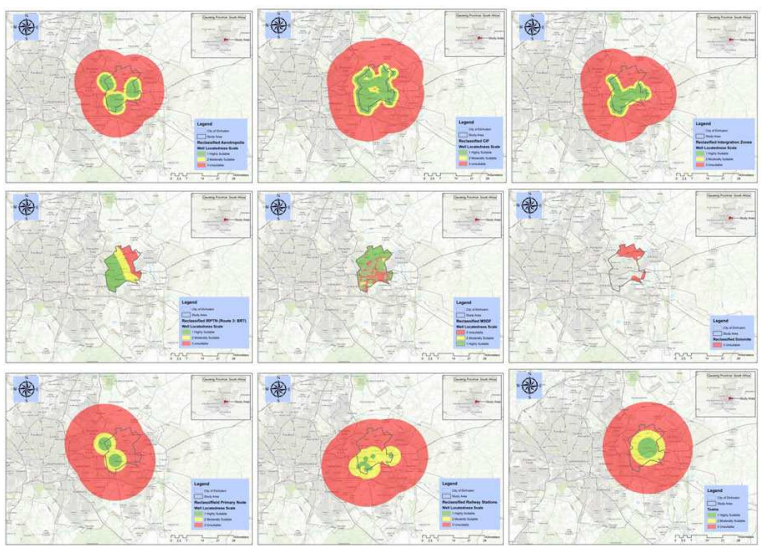

Figure 3: Suitability Criteria Maps (1. Aerotropolis proximity; 2. Capital Investment Framework proximity; 3. Integration zones proximity; 4. IRPTN (BRT route 3 ) proximity; 5 . MSDF suitability; 6 . Dolomite; 7. Primary Node proximity; 8 . Train Station proximity; 8 . Town (CBD) proximity

\footnotetext{
${ }^{4}$ Whether an area is well located or unsuitably located for urban
} development 
According to Antunes et al (2010) the Analytical Hierarchy Process (AHP) or the pairwise comparison, considers four major steps in decision making. The first step is breaking down the problem into a hierarchy of decision elements, the second is using a pair-wise comparison to these elements through the collection of data, the third step is to estimate the relative weights and lastly aggregate these to get a set of ratings for the decision alternatives (Antunes et al, 2010). Another decision making technique is the Recognition Primed Decision Making Theory (RPDM). This technique follows the naturalistic approach to decision making. Unlike other techniques this particularly tries to understand how decisions are made rather than define the decision making process (Antunes et al, 2010). It sorts to understand how things such as uncertainty, ill-defined goals, time pressure and factors affect decision making. This approach endeavours to also highlight the concept of situation awareness as a measure against expectancies, actions and goals as well as cues (Antunes et al, 2010). Once the data has been processed, manipulated and reclassified to the desired outcome, a spatial overlay process is modelled and run using all the criteria selected and the weights assigned by the AHP to develop the Strategic Spatial Urban Development Decision Framework as a Planning Support Systems for expropriation purposes.

Table 2: Criteria and weighting to identify very well-located areas for urban development for expropriation purposes

\begin{tabular}{|l|l|l|}
\hline Category & $\begin{array}{l}\text { Weight } \\
(\%)\end{array}$ & Rank \\
\hline Dolomite Investment & $18.80 \%$ & 1 \\
\hline $\begin{array}{l}\text { Capital } \\
\text { Framework (CIF) }\end{array}$ & $14.10 \%$ & 2 \\
\hline Integration Zones & $14.10 \%$ & 2 \\
\hline Railway Stations Public & $13.00 \%$ & 4 \\
\hline $\begin{array}{l}\text { Integrated Rapid } \\
\text { Transport } \\
\text { (IRPTN) }\end{array}$ & $12.80 \%$ & 5 \\
\hline Primary Nodes & $10.70 \%$ & 6 \\
\hline Aerotropolis Projects & $8.90 \%$ & 7 \\
\hline Towns & $7.70 \%$ & 8 \\
\hline
\end{tabular}

In another example, a Well Located Land Index was developmental, specifically to assist the local government to find strategic land for Human settlement purposes (Mokoena, Musakwa and Moyo, 2017). In this case the rule sets where designed to incorporate 4 categories rather than three. What is found is that the benoni area is largely found to be highly suitable for Human Settlements purposes.
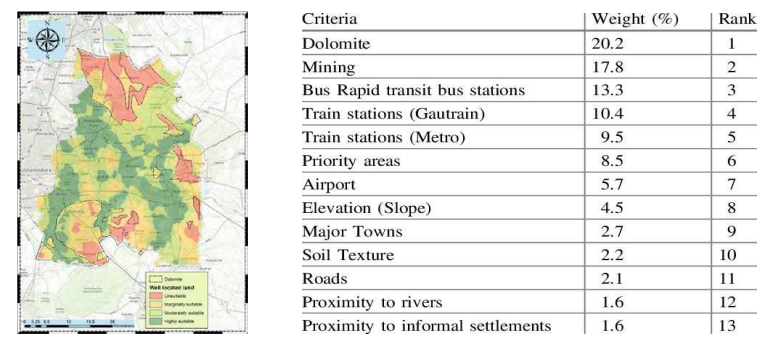

Figure 4: The Well Located Land Index Map and Criteria Weighting for Human settlements in City of Ekurhuleni (Mokoena, Musakwa and Moyo, 2017)

\section{CONCLUSION}

The South African Spatial for has over the years coursed social and economic inequalities that still exist even today. With the 1913 land Act coursing land dispossession, black people in South Africa continue facing unequal ownership of land despite the various interventions by the state regarding in its land reform program.

As cities continue using technology to advance and manage everyday activity and development, smart cities continue to increase. Urban Planners therefore require scientific methods and techniques to make decisions in their work spaces. This paper then endeavoured to apply Evidence Based Planning (EBP) by developing a Strategic Spatial Urban Development Decision Framework (SSUDDF) as a Planning Support Systems using the GIS-MCDA and AHP process as a methodology. The development of the framework enabled us to stream line significant criteria and processes that where specific to strategic urban development in the Benoni town situated in the City of Ekurhuleni. The framework made use of critical spatial policy and strategic documents specific to the City of Ekurhuleni, taking into consideration the environmental constraints and as well as leveraging on the opportunities that can be offered in previously disadvantaged areas. While the Benoni area was used as a study area the framework can be used across the city as well as other local municipalities in South Africa to identify very well located locations for urban development in order to provide service delivery.

\section{REFERENCES}

Behrendt, F., 2016. Why cycling matters for smart cities. Internet of bicycles for intelligent transport. Journal of transport geography, 56, pp.157-164.

Exner, J. P., 2015. Smart cities-field of application for planning support systems in the 21st century. J. Ferreira \& R. Goodspeed (Eds.), pp.1-18.

Caragliu, A., Del Bo, C. and Nijkamp, P., 2011. Smart cities in Europe. Journal of urban technology, 18(2), pp.65-82.

Davenport, T. R. H., 1990. South Africa: A Modern History, 6-8.

Department of Agriculture, Land Reform and Rural Development (DALRRD)., 2019. Land reform in South Africa. Town and Regional Planning, 75, 1-2.

Feinberg, H.M. and Horn, A., 2009. South African Territorial Segregation: New Data on African Farm Purchases, 1913-1936. Journal of African History, 50.

Feinstein, C.H., 2005. An economic history of South Africa: Conquest, discrimination, and development. New York: Cambridge University Press. 
Gibson, J.L., 2009. Overcoming historical injustices: Land reconciliation in South Africa. Cambridge: Cambridge University Press.

Harrison, P. and Huchzermeyer, M., 2003. Confronting fragmentation: housing and urban development in a democratising society. Juta and Company Ltd.

Harrison, P. and Todes, A., 2015. Spatial transformations in a "loosening state": South Africa in a comparative perspective. Geoforum, 61, pp.148-162.

Jankielsohn, R. and Duvenhage, A., 2018. Radical land reform in South Africa - A comparative perspective? Journal for Contemporary History, 42(2), 1-23.

Letsoalo, E.M., 1987. Land Reform in South Africa. Johannesburg: Skotaville.

Ntsebeza, L. and Hall, R. eds., 2007. The land question in South Africa: The challenge of transformation and redistribution. HSRC press.

May, J. and Govender, J., 1998. Poverty and inequality in South Africa. Indicator South Africa, 15, pp.53-58.

Mokoena, B.T., Musakwa, W. and Moyo, T., 2017, July. Developing the Well-Located Land Index to Establish Smart Human Settlements for the Ekurhuleni Municipality, South Africa. In International Conference on Computers in Urban Planning and Urban Management (pp. 95-112). Springer, Cham.

Moyo, S., 2005. The politics of land distribution and race relations in southern Africa. In Racism and public policy (pp. 242-270). Palgrave Macmillan, London.

Moyo, S., 2007. The land question in southern Africa: a comparative review. The Land Question in South Africa: The challenge of transformation and redistribution, pp.60-86.

Murray, M.J., 2008. Taming the disorderly city: The spatial landscape of Johannesburg after apartheid. Ithaca, NY: Cornell University Press.

Myagmartseren, P., Buyandelger, M. and Brandt, S.A., 2017. Implications of a spatial multicriteria decision analysis for urban development in Ulaanbaatar, Mongolia. Mathematical Problems in Engineering, 2017.

Parnell, S. and Pieterse, E., 2010. The 'right to the city': institutional imperatives of a developmental state. International journal of urban and regional research, 34(1), pp.146-162.

Republic of South Africa (RSA)., 1913. Natives Land Act, No. 27 of 1913. (Online). Available at: <http:/ www.ruraldevelopment.gov.za/phocadownload/1913/nativeland act27of1913. pdf $>$ [Accessed: 30 March 2020].

Republic of South Africa (RSA)., 1996. Constitution of the Republic of South Africa. (Online). Available at: https://www.gov.za/documents/ constitution-republic-southafrica-1996 [Accessed: 19 March 2020].

Republic of South Africa (RSA)., 2019. Draft Expropriation Bill. (Online). Available at: https://www.gov.za/sites/default/files/gcis_document/201812/4 2127gon1409s.pdf [Accessed: 10 February 2019].

Republic of South Africa (RSA)., 2019a. Final Report of the Presidential Advisory Panel on Land Reform and Agriculture. For His Excellency the President of South Africa. Pretoria: Republic of South Africa.

Van Wyk, J. 2013. The legacy of the 1913 Black Land Act for spatial planning. Southern African Public Law, 28(1), 91-105.

Worth, S.H. and Abdu-Raheem, K.A. 2011., Household food security in South Africa: Evaluating extension's paradigms relative to the current food security and development goals. South African Journal of Agricultural Extension, 39(2), 91-103.

Malczewski, J. and Rinner, C., 2015. Multicriteria decision analysis in geographic information science. New York: Springer.

Saaty, T.L., 2008. Decision making with the analytic hierarchy process. International journal of services sciences, 1(1), pp.8398.

Santé-Riveira, I., Crecente-Maseda, R. and Miranda-Barrós, D., 2008. GIS-based planning support system for rural land-use allocation. Computers and electronics in agriculture, 63(2), pp.257-273.

Rybarczyk, G. and $\mathrm{Wu}, \mathrm{C} ., 2010$. Bicycle facility planning using GIS and multi-criteria decision analysis. Applied Geography, 30(2), pp.282-293.

Velasquez, M. and Hester, P.T., 2013. An analysis of multicriteria decision making methods. International Journal of Operations Research, 10(2), pp.56-66.

Todes, A., 2012. Urban growth and strategic spatial planning in Johannesburg, South Africa. Cities, 29(3), pp.158-165.

Triantaphyllou, E., 2000. Multi-criteria decision making methods. In Multi-criteria decision making methods: A comparative study (pp. 5-21). Springer, Boston, MA.

Turok, I., 2013. Transforming South Africa's divided cities: can devolution help?. International Planning Studies, 18(2), pp.168187.

Yigitcanlar, T. and Teriman, S., 2015. Rethinking sustainable urban development: towards an integrated planning and development process. International Journal of Environmental Science and Technology, 12(1), pp.341-352.

Fong, P.S.W. and Choi, S.K.Y., 2000. Final contractor selection using the analytical hierarchy process. Construction management and economics, 18(5), pp.547-557.

Akarte, M.M., Surendra, N.V., Ravi, B. and Rangaraj, N., 2001. Web based casting supplier evaluation using analytical hierarchy process. Journal of the Operational Research Society, 52(5), pp.511-522.

D’Sousa, E., Forsyth, A., Koepp, J., Larson, N., Lytle, L., Mishra, N., Oakes, J.M., Schmitz, K.H., Zimmerman, J., Rodriguez, D. and Song, Y., NEAT-GIS. 
Frank, L.D., Greenwald, M.J., Winkelman, S., Chapman, J. and Kavage, S., 2010. Carbonless footprints: promoting health and climate stabilization through active transportation. Preventive medicine, 50, pp.S99-S105. 